\title{
THE PROBLEMS OF HISTORY OF CREATION OF ALISHER NAVOI'S WORKS
}

\author{
Qodirjon Ergashev
}

Institute Of Uzbek Language, Literature And Folklore Of The Academy Of Sciences Of The Republic Of Uzbekistan (Uzbekistan)

\section{ABSTRACT}

This article is devoted to the history of creation of the works of Alisher Navoi. It considers the history of the collection "Hazoin ul - Maoniy" ("Treasury of Thoughts"), the poem Saddi Iskandari (Alexander's Wall) and the religious work Siroj ul-Muslimin ("The Light of Muslims"). The author pays special attention to such issues as the time of compilation of "Hazoin ul -Maoniy "("Treasury of Thoughts") and in what period of the poet's life and conditions the poems were included in the collection. Conclusions obtained because of author's research are set out in the end of the article. The article also clarified the issue related to the history of the creation of Siroj ul -Muslimin ("The Light of Muslims").

KEYWORDS: - Works, poems, creation history, first edition, two years, version, jandarmien.

\section{INTRODUCTION}

One of the peculiarities and important directions of Navoi studies is the study of the history of Alisher Navoi's works, when and under what conditions they were written, what factors and reasons motivated the author to write this or that work, which works were inspired by his predecessors, whose work was written as a taboo? The main sources in the study of Navoi's work in this aspect are the prefaces, epics and other works of his works, information and notes found in various works of the poet, as well as the works of the poet's contemporaries.

The history of Alisher Navoi's works has been studied to some extent. Scholars who have studied this or that work of the author have focused on these issues for the first time. It should be noted that the history of the creation of "Khamsa" and its epics has been studied in great detail. Of course, Navoi himself played a role in this, as he gave detailed information about it, referring to the epics created before him, in particular, the works of Nizami and Khusrav Dehlavi. Nevertheless, there are still issues and confusions that need to be clarified in this regard. An example of this is the misinterpretation of Navoi's account of the history of the work in his research on Saddi Iskandariy. Researcher Ilyas Ismailov rightly noted this in his dissertation on the comparative analysis of the epic "Saddi Iskandariy", because the famous scientist E.E. In Alexandria, he studied the available versions of Alexander's personality and lineage, cited them in his work, and consulted with Jami about their validity or invalidity, and based on his opinion, he saw all three versions (i.e., Faylaqus returning from hunting and seeing a newborn baby and his dying mother in a dilapidated house). he was the first to say that he was the son of Alexander the Great, the second to say that he was born of the daughter of 
CURRENT RESEARCH JOURNAL OF PHILOLOGICAL SCIENCES 2(10): 18-

23, October 2021

DOI: https://doi.org/10.37547/philological-crjps-02-10-04

ISSN 2767-3758

(C)2021 Master Journals

Crossref do

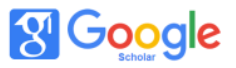

Accepted08 ${ }^{\text {th }}$ October, 2021 \& Published $13^{\text {th }}$ October, 2021

Faylakus, and the third to say that Alexander passed away. Indeed, the following verse, which concludes after Navoi's narration of the above versions, confirms Bertels' view:

Ким ул Файлақус ўғли эрмиш яқин, Эмас ахли тарих тардиди чин.

Thus, as early as 1948, E.E. Bertels gave a clear and unambiguous account of the issue, which is interpreted in Uzbek literature as one of the versions rejected by Navoi, that is, the version of Alexander that was found in a broken house and adopted by Faylaqus. and the part in which this version is narrated is considered to be an integral part of the plot of the epic. The second volume of the history of Uzbek literature, dedicated to the epic "Saddi Iskandariy", describes the content of the epic and includes the above episode. However, this episode, which has absolutely nothing to do with the plot of the epic, is about the history of the creation of the epic.

Despite such confusion, as noted above, the history of the creation of Navoi epics is relatively well studied, and we have enough information about the time of their writing, sources, plot roots. But it is difficult to say the same about the study of the history of the creation of the poet's lyrical devons. With the exception of the first devon, the data given in the research on the years of their formation are different, some of which are approximate, i.e., opinions of such and such a year or so. A number of issues related to the history of the Khazain ulMaoniy complex, which contains the main part of Navoi's lyrical heritage, remain unresolved, and we need to clarify some of them.

According to research, the time of the formation of "Khazain ul-Maoniy" is 1492-1498. This idea was first expressed by the Russian orientalist S.I. Volin. Hamid Suleiman, who later conducted research on Khazain ul-Maani and prepared and published its critical text, agreed. A.Abdugafurov, who drew attention to a number of problems related to this complex and published several articles under the general title "Khazain ul-maoniy" puzzles in an attempt to clarify them, expressed his opinion in this regard: ush-shabab "," Badoe ul-vasat "and" Favoid ul-kibar "devons were first completed in 897 A.D., 1491 A.D. "Is displayed. Four more years later, in 1498, Navoi returned to this work for the third time, reviewing the devons from head to toe, introducing new poems, perfecting them and writing a special preface for the whole complex.

It is impossible to agree with the opinion that Navoi's four divans were first completed in $897 \mathrm{AH}$ and $1491 \mathrm{CE}$, as this conclusion contradicts Navoi's own information on this subject. Navoi writes in Hamsat ul-Mutahayyirin that during a conversation with Jami, Jami advised him to give a name to each of the devons, and accordingly he gave a name to each of his four devons. According to Navoi, the incident took place in the last year of Jami's life. The last year of his life was 1492. He died in November of that year, hence the first formation and naming of the four devons in 1492.

It is possible to agree with the scholar's opinion that Navoi later edited his devons twice (in 1495 and 1498), added new poems, and thus three editions of "Khazain ul-maoniy" appeared.

In this regard, it is useful to pay attention to other facts related to the date of 1498 and to draw some conclusions about the activities and creativity of Alisher Navoi based on them. The point is that several scholars who have studied the poet's other works also mention the above date when talking about their final edition. For example, S. Ganieva writes about Majlis un-nafois: "Majlis un-nafois has two editions, the first edition was made in 896 / 1490-1491, and the second edition in 903 / 1497$1498 "$. 
CURRENT RESEARCH JOURNAL OF PHILOLOGICAL SCIENCES 2(10): 18-

23, October 2021

DOI: https://doi.org/10.37547/philological-crjps-02-10-04

ISSN 2767-3758

(C)2021 Master Journals

Crossref do

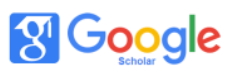

Accepted08 ${ }^{\text {th }}$ October, 2021 \& Published $13^{\text {th }}$ October, 2021

Literary critic Yu. Tursunov notes that the last, third edition of "Munshaot" was made in 1497-1498.

Apparently, in the last years of his life, Navoi felt the need to create perfect edits of several of his works, and he did so. In 1498 such copies of "Khazain ulmaoniy", in 1497-98 "Majlis un-nafois" and "Munshaot" appeared. It is necessary to emphasize another point here. In literary criticism, it is also important to determine the information about what a writer did in what years of his life, what they did, because they allow us to get a fuller picture of the writer's biography and creative activity. The above facts show that in 1497-98 Navoi focused on the work of editing and complementing and perfecting the works whose names are mentioned.

In studying the history of the creation of the Khazain ul-Maani, it is not correct to focus only on issues such as the time of its creation, the composition of the edits, the years of their copying, and so on. It is also important to study in what years or in what periods of the poet's life the poems included in the collection were written. Some of the information that can help clarify these issues is contained in the preface to Khazain ul-Maoniy. They show that most of the poems included in Khazain ul-Maoniy were written during a difficult period of the poet's life, during the years when he was in a state of heartache and anguish. In such a situation, the poet fired all his pain and worked tirelessly. Thus many poems were written in a short time. This information, which is very important in terms of studying the history of the creation of the complex, also raises a number of questions: in what years of the poet's life, how long does it mean to be short?

In addition to the preface of the complex, a letter from Navoi Munshaot will help researchers to clarify the order of the complex "Khazain ulMaoniy", when and how the poems included in it were created. Literary critic A. Abdugafurov drew attention to this letter and the information in it in his article "Puzzles of Khazain ul-Maoniy" and based on them, he pointed out that the "short time" mentioned in the preface was two years. But what years are these? Finding an answer to this question and identifying these years, which were recognized by Alisher Navoi as a difficult and at the same time productive period of his life, is important both in terms of studying the history of Khazain ul-Maoniy and in terms of covering the life and work of the poet. Indeed, according to Navoi, the number of poems created in this short period of time was greater than the number of poems included in the previous two devons. It is clear from this that most of the poems included in Khazain ul-Maoniy were written at that time. Although there is no information about this in the sources, it is suggested in the literature that these two years were 14931494. This conclusion is based on the assumption that after the deaths of Abdurahman Jami and Pahlavon Muhammad, Navoi felt lonely and that the loss of his friends was a great tragedy for him. Nevertheless, it is impossible to agree with this conclusion, because the above-mentioned letter, which is directly related to this issue in terms of its content, does not confirm this opinion, but rather gives grounds to draw other conclusions. Navoi first arranged his poems in the form of four devons and named each of them for the first time in 1492. The letter speaks of this, and it is written in this connection. It clearly states that the poems written in these two years are part of these four divans, and that the poet combines them with the poems in the previous two divans and divides them into four divans. , the air in the head of this slave turned into a hundred different temptations of life ... It was an act of slavery to squander them, and the ruler of the order was a ruler. For this reason, the old two devons were divided into four, and the mountain was divided into four horses. 
CURRENT RESEARCH JOURNAL OF PHILOLOGICAL SCIENCES 2(10): 18-

23, October 2021

DOI: https://doi.org/10.37547/philological-crjps-02-10-04

ISSN 2767-3758

(C)2021 Master Journals

Crossref do

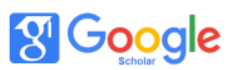

Accepted08th October, 2021 \& Published $13^{\text {th }}$ October, 2021

The fact that the poems written in those two years were included in the first edition of the collection in 1492 denies that they were written in 1493-1494, and refutes the conclusion that Navoi was referring to those years at least two years ago, indicating that Navoi was in fact referring to 1492. Accordingly, we have designated these two years from the middle of 1489 to the middle of 1491 . The question arises, why not $1490-1491$. This is because there is a special note in the preface of Khazayn ul-Maoniy, and according to him, some time has passed between those two years and the first arrangement of the four devons (in Navoi's own words, "fursate").

One of the works of Alisher Navoi, the history of which is described in detail by the author, is "Siroj ul-Muslimin". In the chapter entitled "The Cause of the Poetry of the Book", Navoi gave extensive and detailed information about the history of the creation of "Siroj ul-Muslim" and at the end of the book returned to this issue and added information about the completion of the work. The question arises: why did Navoi pay so much attention to the history of writing this small work of his? Since the research on Siraj ul-Muslimin does not say anything about this, we find it necessary to comment on this. The fact is that "Siroj ul-Muslimin" is a new phenomenon in Navoi's work in terms of its theme and content, and Navoi had not previously written works on religion and belief. Consequently, he wanted to explain to the students the reasons why he addressed the subject in his work and wrote a special work. In addition, in contrast to Navoi's earlier works, which were the product of his own creative intentions and plans, external factors played a key role in the writing of Siroj ul-Muslimin. The author wrote it taking into account the opinions of others about his work. Because these people were very considerate and high-ranking people, the poet wanted them and others to know that he had taken their views into account, and he described all this in detail in his introduction to Siraj ul-Muslim. In particular, the person who was the first to speak on this issue in the royal assembly and was the direct cause of the writing of "Siroj ulMuslimin" and his views:

\section{Эшиттимки , базмининг бир нуктадони, Шохи сохибқироннинг жондармиёни,} Демиш: не суд агар бир уйни тузмиш, Ки назми шайнидин кўп уйни бузмиш,

Ўқуғон эл онинг шеърини пайваст, Тилар бўлғай хамиша ошиқу маст.

Солиб ислому дин уйига ошуб, Бинойи хайр буткармак не махсуб?

As we can see, Navoi does not name the man, and before quoting his words, the king simply finishes by saying about him, "one point of the feast, the soul of the king."

By Shah Sahibkiran, Navoi means Sultan Hussein Boykaro. But who was the soulmate of the king?

The researchers said nothing about it. Literary critics S.Ganieva, O.Davlatov, D.Sh. The Yusupovs also did not know his identity. Therefore, based on the words written by Navoi himself, they are limited to saying that he was "attending the meetings of the King, intelligent and very close to him" (S. Ganieva), "a close person of the Sultan" (O. Davlatov. D. Yusupova).

As a result of our research, we were able to clarify this issue, to identify the "creature". We first mentioned this person in a short article in the Babur Encyclopedia. However, given the purpose and characteristics of the encyclopedia and the fact that this information has nothing to do with Babur's work, we did not find it necessary to dwell on the 
CURRENT RESEARCH JOURNAL OF PHILOLOGICAL SCIENCES 2(10): 18-

23, October 2021

DOI: https://doi.org/10.37547/philological-crjps-02-10-04

ISSN 2767-3758

(C2021 Master Journals

Crossref do

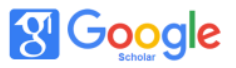

Accepted08th October, 2021 \& Published $13^{\text {th }}$ October, 2021

fact that this person is involved in the history of Siraj ul-Muslim.

"Jondarmiyon" is the nickname of Sheikh Abusaidbek, a contemporary of Alisher Navoi, who served at the same time in the palace of Sultan Hussein Boykaro. Sheikh Abusaidbek or Amir Sheikh Abusaid is a well-known person, information about him can be found in the works of Mirkhand, Khandamir, as well as in "Boburnoma". The author of "Boburnoma" writes about why he gave such a nickname to Sheikh Abusaidbek:

Sheikh Abusaid gained great attention in the presence of the gendarmerie Sultan Hussein Boykaro. This is not in vain, because he served the king faithfully for many years, showing courage in battles. Sources say that he took part in political and military operations and wars during the years when Sultan Hussein fought for the throne. In particular, in 1469 he took part in the battle between Hussein Boykaro and Yodgor Mirza. The sultan appointed him, along with Mogulbek and Hasanshaikh Temur, as part of the army. In 1470, Sultan Hussein made a surprise attack, capturing Herat and sending several beys to occupy the gate of the Garden of Zogan. Among them was Sheikh Abusaidbek. It is known that Alisher Navoi also took part in the battles against Yodgor Mirzo.

Sheikh Abusaid was a valiant warrior of the gendarmerie, a warrior, as well as a man of great knowledge, in particular, a well-versed in literature, a noble and mature man. Navoi did not describe him as a "nuktadon" for nothing. Sheikh Abusaid Husayn was a regular participant in literary gatherings at the Boykaro Palace, a close interlocutor of the sultan. Alisher Navoi also had great respect for him because of the abovementioned qualities. This can be seen in the fact that Navoi accepted Sheikh Abusaid's views on his work without any objections and decided to write a special work on the issues of religion and belief: Тушуб бу нуктадин жисмим аро печ, Чу билдим чин эрмиш, дам урмадим хеч. Дедимким, айлайин бир нусха маъмур, Ки бўлғай дину ислом уйи маъмур.

It should be noted that the information provided by the author on the history of the creation of "Siroj ulMuslimin" has in some cases been misinterpreted. The foreword to the 1993 edition of the work, published by the Nur Creative Production Association, refers to Hussein Boykaro in an excerpt from Navoi's work, which begins with "I heard that the point of the party."

We have mentioned above that Sheikh Abusaid was a well-known figure of his time, and his name appears in the works of Mirkhand, Khandamir, Babur. In the editions of these works, the name and nickname of Sheikh Abusaid Jandarmiyon are written differently. In one part of the book "In the memory of Navoi's contemporaries" Abusaidjon is mentioned in the form of a dormon, and in the edition "Boburnoma" Sheikh Abusaidkhan is given in the form of a drug.

Naturally, it is impossible to cover all the issues related to the history of Alisher Navoi's works in one article. Therefore, research in this area should be continued.

\section{REFERENCES}

1. А.Хайитметов. "Тарихи мулуки Ажам". Ўзбек адабиёти тарихи. 5 томлик, 2-том, 448-бет. Тошкент, “Фан” 1977.

2. С.Ғаниева. Алишер Навоийнинг прозаик асарлари. Тошкент, “Ўзбекистон”, 1981. 24-бет.

3. Қ.Эргешев. “Тарихи мулуки Ажам” да тарихий хақиқат ва афсонавий-романтик талқин. ЎТА, 2006 йил, 5-сон.21-25 бетлар.

4. Қ.Эргашев. “Тарих ахлининг ихтилофи 
CURRENT RESEARCH JOURNAL OF PHILOLOGICAL SCIENCES 2(10): 18-

23, October 2021

DOI: https://doi.org/10.37547/philological-crjps-02-10-04

ISSN 2767-3758

(C)2021 Master Journals

Crossref dol 81 Google

Accepted08 ${ }^{\text {th }}$ October, $2021 \&$ Published $13^{\text {th }}$ October, 2021

кўптур”. ЎзАС, 2001йил 18-май.

5. Алишер Навоий. “Тарихи мулуки Ажам” 10

жилдлик, 8-жилд.Тошкент, 2011 йил.623-

624 бетлар.

6. Алишер Навоий. “Тарихи анбиё ва хукамо” 10 жилдли, 8-жилд. Тошкент, 2011 йил,

542-бет 